Zeszyty Naukowe Szkoły Głównej Gospodarstwa Wiejskiego w Warszawie

Problemy Rolnictwa Światowego tom 18 (XXXIII), zeszyt 1, 2018: 111-120

DOI: $10.22630 /$ PRS.2018.18.1.10

Dorota Komorowska $^{1}$

Szkoła Główna Gospodarstwa Wiejskiego w Warszawie

\title{
Wyniki produkcyjne i ekonomiczne gospodarstw ogrodniczych
}

\section{Production and Economic Results of Horticultural Farms}

\begin{abstract}
Synopsis. Celem opracowania jest ocena wyników gospodarowania zasobami produkcyjnymi w gospodarstwach nastawionych na produkcję ogrodniczą na tle wyników ogółu gospodarstw rolnych, które były objęte rachunkowością rolną w systemie FADN w latach 2013-2015. Analizie poddano wyniki produkcyjne i ekonomiczne oraz produktywność i dochodowość zasobów ziemi, pracy i kapitału. Zaprezentowane w opracowaniu wyniki badanych gospodarstw wskazują na znacznie wyższy poziom efektywności produkcyjnej zasobów w gospodarstwach ogrodniczych, zwłaszcza produktywności ziemi, ale także kapitału. Gospodarstwa specjalizujące się w produkcji ogrodniczej uzyskały wyniki ekonomiczne na kilkukrotnie wyższym poziomie niż gospodarstwa ogółem, dlatego przewyższały je bardziej efektywnością ekonomiczną niż produkcyjną, zwłaszcza w gospodarowaniu zasobami ziemi, jak również kapitału. Dopłaty do działalności gospodarstw ogrodniczych nie mają dużego wpływu na poziom dochodów uzyskiwanych przez te gospodarstwa.
\end{abstract}

Słowa kluczowe: produkcja ogrodnicza, wyniki produkcji rolniczej, efektywność gospodarowania zasobami w rolnictwie

\begin{abstract}
The aim of the study is to evaluate the results of management of production resources in farms oriented for horticultural production against the background of the results of all farms that were covered by FADN agricultural accounting for 2013-2015. Production and economic results like productivity and profitability of land, labor and capital were analyzed. The results of the surveyed farms show a much higher level of production efficiency of horticultural holdings, especially the productivity of land resources, but also of capital. Farms specializing in horticulture achieved economic results several times better than that of total holdings, therefore they outperformed them more economically than by production, especially in the management of land resources as well as capital. Subsidies to horticultural holdings do not have a significant impact on the level of income earned by these holdings.
\end{abstract}

Key words: horticultural production, results of agricultural production, resource efficiency in agriculture

JEL Classification: Q12

\section{Wstęp}

Uprawa warzyw w Polsce zajmuje nieco ponad 1\% powierzchni użytków rolnych, ale udział produkcji warzywniczej w wartości towarowej produkcji rolniczej wynosi ok. 10\% (Rolnictwo..., 2016). Rozwojowi produkcji warzyw w naszym kraju sprzyjają takie czynniki, jak: rosnąca siła nabywcza konsumentów, duże zasoby pracy w rolnictwie i relatywnie niskie jej koszty oraz rozwinięty przemysł przetwórczy. Ważnym czynnikiem

${ }^{1}$ dr hab. inż., Katedra Ekonomiki Rolnictwa i Międzynarodowych Stosunków Gospodarczych SGGW, ul. Nowoursynowska 166,02-787 Warszawa, e-mail: dorota_komorowska@sggw.pl, https://orcid.org/0000-0002-9881-7785 
stymulującym rozwój krajowej produkcji warzywniczej jest także jej eksport. Po wejściu Polski do Unii Europejskiej (UE) odnotowano wzrost wolumenu eksportu większości gatunków warzyw i ich przetworów (Jąder, 2017). W 2015 roku wolumen polskiego eksportu warzyw świeżych i przetworzonych wyniósł 470 tys. ton i był o ponad $40 \%$ większy niż w pierwszym roku członkostwa Polski w UE (Rynek rolny..., 2017). Wzrostowi eksportu sprzyjała dobra jakość polskich warzyw oraz konkurencyjne ceny (Nosecka, 2014, Pawlak, 2014).

Obserwowane zmiany, jakie zachodzą w krajowej produkcji warzywniczej przejawiają się w poprawie organizacji i koncentracji produkcji, specjalizacji gospodarstw i wprowadzaniu do uprawy nowych i bardziej wydajnych odmian, a także w usprawnianiu dystrybucji, do czego przyczyniły się uwarunkowania organizacyjno-prawne rynku owoców i warzyw (regulacje prawne, wsparcie finansowe wspólnej organizacji rynku, zmiany w zakresie i formach pomocy dla grup producentów) (Filipiak, 2014). W efekcie odnotowano wysoką dynamikę wzrostu plonów i średniego areału uprawy warzyw.

W latach 2000-2014 liczba gospodarstw zajmujących się produkcją warzywnicza zmniejszyła się o $67,5 \%$, natomiast przeciętna powierzchnia upraw warzywniczych w tym okresie wzrosła ponad trzykrotnie i był to największy wzrost w obrębie krajów unijnych (Jabłońska i in., 2016). Ponadto powierzchnia uprawy i zbiory warzyw w tym okresie także wzrosły, a u pozostałych głównych producentów unijnych zmniejszyły się. Dlatego produkcja warzyw w Polsce kształtuje się na poziomie około $10 \%$ produkcji warzywniczej w UE i czyni Polskę czwartym producentem warzyw we Wspólnocie po Włoszech, Hiszpanii i Francji. Jesteśmy największym unijnym producentem kapusty, marchwi oraz buraków ćwikłowych, a w produkcji ogórków i cebuli zajmujemy drugie miejsce (Brzozowski, Zmarlicki, 2015), chociaż nasze gospodarstwa zajmujące się produkcją warzyw nie są jeszcze tak wyspecjalizowane, jak w innych krajach unijnych o znaczących rozmiarach tej produkcji. Z porównania polskich gospodarstw warzywniczych $\mathrm{z}$ analogicznymi gospodarstwami w krajach UE o zbliżonej strukturze agrarnej i podobnych warunkach produkcyjnych wynika, że polskie gospodarstwa warzywnicze są zdecydowanie mniej wyspecjalizowane (Ziętara, Sobierajewska, 2012).

Do rozwoju krajowej produkcji warzywniczej przyczyniły się również tendencje w spożyciu warzyw i ich przetworów, tendencje w handlu zagranicznym produktami warzywnictwa oraz wymagania odbiorców produktów warzywniczych, w tym sieci handlowych w zakresie wielkości dostaw i standaryzacji produktów (Filipiak, 2014). Można spodziewać się, że popyt na warzywa i przetwory warzywne będzie rósł ze względu na ich duże znaczenie w codziennej diecie, a zarazem będzie postępował dalszy rozwój ich produkcji, zwłaszcza przy rosnącej tendencji w eksporcie warzyw i ich przetworów. Różnice cen skupu warzyw przeznaczanych na eksport i kierowanych do przetwórstwa powoduja, że ich zagospodarowanie poprzez eksport jest dla producentów bardziej opłacalne niż ich sprzedaż do zakładów przetwórczych (Nosecka i in., 2012), co sprzyja rozwojowi produkcji pod kątem eksportu.

Obserwowany rozwój krajowego warzywnictwa, postępujące procesy koncentracji produkcji i specjalizacji gospodarstw zachęcaja do oceny wyników gospodarowania zasobami w gospodarstwach nastawionych na produkcję warzyw. 


\section{Materiał i metodyka badań}

Celem opracowania jest ocena wyników gospodarowania zasobami produkcyjnymi w gospodarstwach ogrodniczych na tle wyników ogółu gospodarstw rolnych, które były objęte rachunkowością rolną w systemie $\mathrm{FADN}^{2}$ w latach 2013-2015. W ramach systemu rachunkowości rolnej FADN gospodarstwa rolne są grupowane m.in. według typów produkcyjnych, określanych na podstawie udziału wartości produkcji z poszczególnych działalności rolniczych $\mathrm{w}$ wartości produkcji całkowitej gospodarstwa. W ich obrębie jest typ ,gospodarstwa ogrodnicze”, który grupuje gospodarstwa specjalizujące się w produkcji warzyw, truskawek, grzybów, kwiatów i roślin ozdobnych (nie ujmuje gospodarstw sadowniczych). Wartość uzyskiwanej produkcji warzyw w tego typu gospodarstwach wynosi około 90\% wartości produkcji całkowitej (tab. 2). W związku z tym gospodarstwa ogrodnicze są przedmiotem analizy porównawczej w niniejszym opracowaniu, natomiast zgodnie z założeniami obowiązującego systemu rachunkowości rolnej, badaniem zostały objęte tylko gospodarstwa przekraczające minimalny próg wielkości ekonomicznej (tzw. gospodarstwa towarowe) (Goraj, Mańko, 2009).

Według metodyki FADN, wyniki produkcyjne gospodarstw rolnych stanowi kategoria „produkcja ogółem”, czyli produkcja całkowita, która obejmuje produkcję rolniczą roślinną i zwierzęcą oraz pozostałą produkcję, a także przychody z dzierżawienia ziemi, wynajmu budynków, maszyn, świadczenia usług. Natomiast kategoria dochodowa według tejże metodyki to „dochód z rodzinnego gospodarstwa rolnego", określana w niniejszym opracowaniu w skrócie jako „dochód z gospodarstwa rolnego”. Odpowiada dochodowi rolniczemu netto $\mathrm{z}$ uwzględnieniem dopłat do działalności gospodarstw rolnych. W celu określenia znaczenia dopłat $\mathrm{w}$ kształtowaniu poziomu dochodów badanych gospodarstw obliczono „dochód z gospodarstwa rolnego bez dopłat” oraz „dochód z gospodarstwa rolnego z dopłatami".

Efektywność gospodarowania zasobami produkcyjnymi w gospodarstwach rolnych mierzy się odnosząc ujęcie wartościowe efektów produkcyjnych oraz wyniki ekonomiczne gospodarstw do wkładu czynników wytwórczych zaangażowanych w ich uzyskanie (Józwiak, 1998, Kapusta, 2012). Odniesienie odpowiednio wyników produkcyjnych pozwala ocenić efektywność produkcyjna, a wyników ekonomicznych - efektywność ekonomiczną. Odniesienie wartości uzyskanej produkcji do wielkości zasobów ziemi użytkowanych w analizowanych gospodarstwach pozwoliło ustalić produktywność zasobów ziemi. Odniesienie wartości produkcji do wielkości wkładu pracy w jej wytworzenie (wkładu pracy przeliczonego na pełny wymiar czasu pracy) pozwoliło obliczyć produktywność wydatkowanej pracy (ekonomiczną wydajność pracy). Natomiast przeliczenie wartości produkcji na $100 \mathrm{zł} \mathrm{zaangażowanego} \mathrm{kapitału} \mathrm{w} \mathrm{procesy} \mathrm{wytwarzania}$ porównywanych gospodarstw pozwoliło ustalić produktywność kapitału przypadającą na jego jednostkę. $Z$ kolei odniesienie odpowiednio wyniku ekonomicznego (dochodu z gospodarstwa rolnego z dopłatami) do wkładu zasobów produkcyjnych zaangażowanych w jego uzyskanie pozwoliło ocenić efektywność ekonomiczną gospodarowania zasobami w badanych gospodarstwach (dochodowość zasobów ziemi, wydatkowanej pracy i zaangażowanego kapitału).

\footnotetext{
${ }^{2}$ FADN to jednolity system zbierania danych rachunkowych we wszystkich krajach członkowskich UE, służący m.in. do kreowania wspólnej polityki rolnej. W Polsce od 2004 roku IERiGŻ-PIB prowadzi badania rachunkowości rolnej w systemie FADN, określanym jako Polski FADN.
} 


\section{D. Komorowska}

\section{Zasoby produkcyjne}

Przeciętna powierzchnia użytków rolnych (UR) porównywanych grup gospodarstw różniła się znacząco. Gospodarstwa nastawione na produkcję ogrodniczą były ponad trzykrotnie mniejsze obszarowo od ogółu gospodarstw rolnych, ich średnia powierzchnią UR wyniosła ok. 6,0 ha, natomiast gospodarstw ogółem - ok. 20,0 ha. Zarówno gospodarstwa ogrodnicze, jak i gospodarstwa ogółem gospodarowały zasobami ziemi, które były częściowo dzierżawione (tab. 1.). Na podkreślenie zasługuje fakt, że pod względem wielkości obszarowej, przeciętne polskie gospodarstwo ogrodnicze różni się nieznacznie od unijnego, ponieważ średnia powierzchnia UR gospodarstwa ogrodniczego w krajach UE w 2014 roku wyniosła ok. 7,0 ha (średnia powierzchnia dla ogółu unijnych gospodarstw w tymże roku wynosiła ok. 32 ha) (Farm economy... 2017).

$\mathrm{W}$ oparciu o dane rachunkowości rolnej FADN z zakresu zasobów pracy gospodarstw rolnych można podać tylko wkład zasobów pracy w procesy produkcyjne gospodarstw, czyli nakłady pracy. $Z$ danych rachunkowych wynika, że roczne nakłady pracy ogółem $\mathrm{w}$ przeliczeniu na pełnozatrudnionego $\mathrm{w}$ ciagu roku ( $\mathrm{w} \mathrm{AWU}^{3}$ ) były znacznie większe $\mathrm{w}$ gospodarstwach ogrodniczych, co wynikało $\mathrm{z}$ pracochłonnej produkcji $\mathrm{w}$ tego typu gospodarstwach. Pracochłonność produkcji gospodarstw ogrodniczych (mierzona poziomem nakładów pracy na 1 ha UR) była ponad pięciokrotnie większa niż ogółu gospodarstw. W związku z tym gospodarstwa specjalizujące się w produkcji ogrodniczej angażowały w dużym udziale nakłady pracy najemnej (ponad 40\%).

Tabela 1. Zasoby produkcyjne porównywanych grup gospodarstw w latach 2013-2015

Table 1. Production resources of comparable farm groups in 2013-2015

\begin{tabular}{l|rrrrrr}
\hline \multicolumn{1}{c}{ Wyszczególnienie } & \multicolumn{3}{c}{ Gospodarstwa } \\
& \multicolumn{3}{c}{ ogółem } & \multicolumn{4}{c}{ ogrodnicze } \\
& 2013 & 2014 & 2015 & 2013 & 2014 & 2015 \\
\hline Liczba gospodarstw & 12322 & 12330 & 12313 & 364 & 349 & 354 \\
Średnia powierzchnia użytków rolnych [ha] & 20,3 & 19,5 & 19,4 & 5,7 & 5,7 & 6,0 \\
- w tym dzierżawionych [ha] & 6,1 & 5,3 & 5,1 & 1,2 & 1,1 & 1,1 \\
Nakłady pracy ogółem [AWU] & 1,75 & 1,71 & 1,69 & 2,76 & 2,59 & 2,62 \\
- w tym pracy najemnej [AWU] & 0,26 & 0,22 & 0,22 & 1,15 & 1,04 & 1,05 \\
Nakłady pracy ogółem na 1 ha [AWU] & 0,09 & 0,09 & 0,09 & 0,48 & 0,45 & 0,44 \\
Aktywa ogółem [zł] & 715529 & 711672 & 722420 & 560559 & 552807 & 587639 \\
Aktywa ogółem na 1 ha [zł] & 35248 & 36496 & 37238 & 98344 & 96984 & 97940 \\
\hline
\end{tabular}

Źródło: obliczenia własne na podstawie (Wyniki standardowe..., 2014, 2015, 2016).

Potencjał zasobów kapitałowych gospodarstw rolnych stanowią środki produkcyjne trwałe i obrotowe, których wartość obrazują aktywa ogółem. Zasoby kapitałowe porównywanych grup gospodarstw stanowiły w głównej mierze środki trwałe, w tym budynki i ich trwałe wyposażenie, maszyny, urządzenia, sprzęt nawadniający, środki transportu. Ich wartość w przeliczeniu na 1 ha UR, czyli kapitałochłonność produkcji była

\footnotetext{
${ }^{3}$ AWU - jednostka przeliczeniowa nakładów pracy według metodyki FADN: 1 jednostka AWU $=2120$ godzin pracy ogółem/rok. W nakładach pracy ogółem ujmuje się nakłady pracy własnej rolnika i jego rodziny (FWU) oraz nakłady pracy najemnej (AWU).
} 
ponad dwukrotnie większa w gospodarstwach ogrodniczych, ponieważ znaczna część produkcji w tego typu gospodarstwach jest prowadzona pod osłonami.

\section{Wyniki produkcyjne i produktywność czynników wytwórczych}

Wartość produkcji ogółem w analizowanych gospodarstwach specjalizujących się w produkcji ogrodniczej kształtowała przede wszystkim produkcja warzyw, która stanowiła ok. 90\% wartości produkcji całkowitej (tab. 2.). Niewielki udział w wynikach analizowanych gospodarstw ogrodniczych miała produkcja zwierzęca (niespełna 0,5\%), natomiast wyniki produkcyjne ogółu gospodarstw kształtowała blisko w połowie (47-49\%). W gospodarstwach ogółem dominowała produkcja zbóż, która zajmowała ponad 50\% powierzchni UR i stanowiła 23-25\% wartości produkcji całkowitej. Znaczący udział w wynikach produkcyjnych ogółu gospodarstw miała produkcja mleka (ponad 15\%), żywca wieprzowego (ponad 10\%), a także warzyw (ok. 10\%).

Tabela 2. Wartość i struktura produkcji porównywanych grup gospodarstw w latach 2013-2015

Table 2. Production value and structure of compared farm groups in 2013-2015

\begin{tabular}{|c|c|c|c|c|c|c|}
\hline \multirow{3}{*}{ Wyszczególnienie } & \multicolumn{6}{|c|}{ Gospodarstwa } \\
\hline & \multicolumn{3}{|c|}{ ogółem } & \multicolumn{3}{|c|}{ ogrodnicze } \\
\hline & 2013 & 2014 & 2015 & 2013 & 2014 & 2015 \\
\hline & \multicolumn{6}{|c|}{ Wartość produkcji [zł] } \\
\hline Produkcja ogółem & 141919 & 127195 & 122407 & 230375 & 212328 & 257184 \\
\hline Produkcja roślinna, w tym: & 71529 & 63928 & 63736 & 228225 & 210134 & 255553 \\
\hline - zboża & 32640 & 31256 & 28094 & 4939 & 4536 & 5636 \\
\hline - ziemniaki & 4575 & 3143 & 3587 & 1155 & 642 & 430 \\
\hline - warzywa & 10863 & 10760 & 12653 & 198810 & 183863 & 231342 \\
\hline - owoce & 6834 & 4713 & 6514 & 3465 & 1959 & 2006 \\
\hline Produkcja zwierzęca, w tym: & 68752 & 61649 & 57250 & 1141 & 914 & 966 \\
\hline - mleko & 25554 & 22383 & 18578 & 109 & 117 & 91 \\
\hline \multirow[t]{2}{*}{ - żywiec wieprzowy } & 19961 & 15040 & 13528 & 411 & 236 & 309 \\
\hline & \multicolumn{6}{|c|}{ Struktura produkcji [\%] } \\
\hline Produkcja ogółem & 100,0 & 100,0 & 100,0 & 100,0 & 100,0 & 100,0 \\
\hline Produkcja roślinna, w tym: & 50,4 & 50,3 & 52,1 & 99,1 & 99,0 & 99,4 \\
\hline - zboża & 23,0 & 24,6 & 23,0 & 2,1 & 2,1 & 2,2 \\
\hline - ziemniaki & 3,2 & 2,5 & 2,9 & 0,5 & 0,3 & 0,2 \\
\hline - warzywa & 7,7 & 8,5 & 10,3 & 86,3 & 86,6 & 90,0 \\
\hline - owoce & 4,8 & 3,7 & 5,3 & 1,5 & 0,9 & 0,8 \\
\hline Produkcja zwierzęca, w tym: & 48,4 & 48,5 & 46,8 & 0,5 & 0,4 & 0,4 \\
\hline- mleko & 18,0 & 17,6 & 15,2 & 0,1 & 0,1 & 0,1 \\
\hline - żywiec wieprzowy & 14,1 & 11,8 & 11,1 & 0,2 & 0,1 & 0,1 \\
\hline
\end{tabular}

Źródło: jak w tab. 1.

Według danych GUS-u, w analizowanych latach 2013-2015 widoczny był wyraźny wpływ warunków pogodowych na wyniki produkcyjne w rolnictwie. W 2015 roku w porównaniu z rokiem poprzednim na skutek dużego deficytu opadów i bardzo wysokich 
temperatur odnotowano znaczny spadek wartości produkcji roślinnej (o 11,2\%) w związku ze zmniejszeniem zbiorów większości ziemiopłodów (Rolnictwo..., 2016). Zbiory warzyw zmniejszyły się z 5607 tys. ton w 2014 roku do 4795 tys. ton w 2015 r., tj. o 15\%, dlatego ceny większości gatunków warzyw ze zbiorów w 2015 roku znacznie wzrosły (Rynek owoców..., 2017). W związku z tym wartość uzyskanej produkcji warzyw w 2015 r. w porównaniu z rokiem poprzednim także wzrosła - odpowiednio z 8974 do $9858 \mathrm{mln}$ zł, tj. o 10\% (Rolnictwo..., 2016). Wzrost wartości uzyskanej produkcji warzyw w tym okresie miał również miejsce w badanych gospodarstwach (tab. 2). W gospodarstwach ogrodniczych wartość produkcji warzyw wzrosła o ponad $25 \%$, dlatego wartość produkcji ogółem w tych gospodarstwach także znacznie wzrosła (o 21\%).

Tabela 3. Produktywność zasobów analizowanych gospodarstw w latach 2013-2015

Table 3. Resource productivity in analyzed farms in 2013-2015

\begin{tabular}{l|rrrrrr}
\hline \multicolumn{1}{c|}{ Wyszczególnienie } & \multicolumn{3}{c}{ Gospodarstwa } \\
& \multicolumn{3}{c}{ ogółem } & \multicolumn{4}{c}{ ogrodnicze } \\
& \multicolumn{1}{c}{2013} & 2014 & 2015 & 2013 & 2014 & 2015 \\
\hline Produktywność ziemi [zł/ha] & 6991 & 6523 & 6310 & 40417 & 37250 & 42864 \\
Ekonomiczna wydajność pracy [zł/AWU] & 81004 & 74470 & 72430 & 83499 & 81980 & 98162 \\
Produktywność na 100 zł aktywów ogółem [zł] & 19,8 & 17,9 & 16,9 & 41,1 & 38,4 & 43,8 \\
\hline
\end{tabular}

Źródło: jak w tab. 1.

Odniesienie wyników produkcyjnych porównywanych gospodarstw do wkładu czynników wytwórczych zaangażowanych w ich uzyskanie pozwoliło obliczyć produktywność zasobów analizowanych grup gospodarstw (tab. 3.). W związku z tym, że gospodarstwa ogrodnicze były ponad trzykrotnie mniejsze obszarowo od gospodarstw ogółem a ich wyniki produkcyjne ukształtowały się na znacznie wyższym poziomie to efektywność produkcyjna ich zasobów ziemi była wielokrotnie większa niż ogółu gospodarstw. W latach 2013-2014 produktywność zasobów ziemi w gospodarstwach ogrodniczych była ponad pięciokrotnie większa, a w 2015 r. - ponad sześciokrotnie. Produktywność wydatkowanej pracy i zaangażowanego kapitału była także większa w gospodarstwach specjalizujących się w produkcji ogrodniczej, zwłaszcza produktywność zaangażowanego kapitału (ponad dwukrotnie większa).

\section{Wyniki ekonomiczne i dochodowość czynników wytwórczych}

Dochód z rodzinnego gospodarstwa rolnego stanowi opłatę zaangażowania czynników wytwórczych gospodarstw rolnych w ich procesy produkcyjne. Syntetyczny rachunek wyników ekonomicznych porównywanych grup gospodarstw przedstawiono w tabeli 4. Gospodarstwa nastawione na produkcję ogrodniczą uzyskały znacznie wyższy poziom wyników produkcyjnych niż gospodarstwa ogółem (w latach 2013-2014 o ponad 60\%, w 2015 r. o 110\%), natomiast ich koszty produkcji nie były aż tak wyraźnie wyższe (o ponad 30\%).

Koszty materiałowe działalności produkcyjnej gospodarstw ogrodniczych wynikały przede wszystkim z kosztów nasion i sadzonek, kosztów nawożenia i ochrony roślin, a także kosztów opału i zużytej energii elektrycznej (znaczna część produkcji w tego typu 
gospodarstwach jest prowadzona pod osłonami). Koszty materiałowe ogółu gospodarstw rolnych ukształtowały $\mathrm{w}$ dużym stopniu koszty związane $\mathrm{z}$ produkcją zwierzęca, w tym głównie koszty żywienia zwierząt. Koszty materiałowe zarówno gospodarstw ogrodniczych, jak i ogółu gospodarstw rolnych stanowiły około 70\% kosztów całkowitych tychże grup gospodarstw.

Tabela 4. Rachunek wyników porównywanych gospodarstw w latach 2013-2015

Table 4. Income statement in comparable farms in 2013-2015

\begin{tabular}{|c|c|c|c|c|c|c|}
\hline \multirow{3}{*}{ Wyszczególnienie } & \multicolumn{6}{|c|}{ Gospodarstwa } \\
\hline & \multicolumn{3}{|c|}{ ogółem } & \multicolumn{3}{|c|}{ ogrodnicze } \\
\hline & 2013 & 2014 & 2015 & 2013 & 2014 & 2015 \\
\hline & \multicolumn{6}{|c|}{ Rachunek wyników [zł] } \\
\hline Produkcja ogółem & 141919 & 127195 & 122407 & 230375 & 212328 & 257184 \\
\hline Koszty materiałowe & 93967 & 85392 & 81830 & 118372 & 111395 & 127805 \\
\hline Koszty amortyzacji & 20769 & 19693 & 20591 & 26243 & 25315 & 28275 \\
\hline $\begin{array}{l}\text { Koszty zewnętrznych czynników } \\
\text { produkcji }\end{array}$ & 11590 & 9563 & 9751 & 27680 & 24870 & 25166 \\
\hline Podatki, opłaty & 1859 & 1640 & 1674 & 634 & 589 & 602 \\
\hline Saldo podatku VAT & -903 & -1003 & -1007 & -494 & -501 & -607 \\
\hline Koszty ogółem & 129088 & 117291 & 114853 & 173423 & 162670 & 182455 \\
\hline $\begin{array}{l}\text { Dochód } \mathrm{z} \text { gospodarstwa rolnego } \\
\text { bez dopłat }\end{array}$ & 12831 & 9904 & 7554 & 56952 & 49658 & 74729 \\
\hline Dopłaty & 27757 & 26223 & 25533 & 7753 & 8094 & 10789 \\
\hline \multirow[t]{2}{*}{$\begin{array}{l}\text { Dochód z gospodarstwa rolnego } \\
\text { z dopłatami }\end{array}$} & 40588 & 36127 & 33087 & 64707 & 57752 & 85518 \\
\hline & \multicolumn{6}{|c|}{ Rachunek wyników [zł/ha] } \\
\hline Produkcja ogółem & 6991 & 6523 & 6310 & 40417 & 37250 & 42864 \\
\hline Koszty materiałowe & 4629 & 4379 & 4218 & 20767 & 19543 & 21301 \\
\hline Koszty amortyzacji & 1023 & 1010 & 1061 & 4604 & 4441 & 4713 \\
\hline $\begin{array}{l}\text { Koszty zewnętrznych czynników } \\
\text { produkcji }\end{array}$ & 571 & 490 & 503 & 4856 & 4363 & 4194 \\
\hline Podatki, opłaty & 92 & 84 & 86 & 111 & 103 & 100 \\
\hline Saldo podatku VAT & -44 & -51 & -52 & -87 & -88 & -101 \\
\hline Koszty ogółem & 6359 & 6015 & 5920 & 30425 & 28539 & 30409 \\
\hline $\begin{array}{l}\text { Dochód } \mathrm{z} \text { gospodarstwa rolnego } \\
\text { bez dopłat }\end{array}$ & 632 & 508 & 389 & 9992 & 8712 & 12455 \\
\hline Dopłaty & 1367 & 1345 & 1316 & 1360 & 1420 & 1798 \\
\hline $\begin{array}{l}\text { Dochód z gospodarstwa rolnego } \\
\text { z dopłatami }\end{array}$ & 1999 & 1853 & 1706 & 11352 & 10132 & 14253 \\
\hline
\end{tabular}

Źródło: jak w tab. 1.

Gospodarstwa ogrodnicze prowadzą intensywną działalność produkcyjną (Jabłońska i in., 2017), na co wskazuje poziom kosztów całkowitych, a także kosztów materiałowych w przeliczeniu na 1 ha UR. Intensywność produkcji $\mathrm{w}$ analizowanych gospodarstwach ogrodniczych była kilkukrotnie większa niż w gospodarstwach ogółem (tab. 4.).

Koszty amortyzacji środków trwałych były także wyższe w gospodarstwach specjalizujących się $\mathrm{w}$ produkcji ogrodniczej, ponieważ kapitałochłonność produkcji w tych gospodarstwach była ponad dwukrotnie większa (tab. 1.). Ponadto wyższe w nich były także koszty zewnętrznych czynników produkcji (ponad dwukrotnie), głównie w związku z wyższymi kosztami wynagrodzeń, gdyż gospodarstwa ogrodnicze angażowały 
dużo większe nakłady pracy najemnej (pracochłonność produkcji gospodarstw ogrodniczych była ponad pięciokrotnie większa niż ogółu gospodarstw). Podatki i inne opłaty od ziemi, budynków oraz ujemne saldo podatku VAT było większe w gospodarstwach ogółem.

W rezultacie, wyniki ekonomiczne (dochód z gospodarstwa rolnego bez dopłat) badanych gospodarstw specjalizujących się w produkcji ogrodniczej ukształtowały się na wielokrotnie wyższym poziomie niż gospodarstw ogółem, zwłaszcza w 2015 roku. W tymże roku dochód przeciętnego gospodarstwa ogrodniczego był prawie dziesięciokrotnie wyższy i wyniósł 74729 zł, natomiast przeciętny dochód ogółu gospodarstw rolnych $-7554 \mathrm{zl}$.

W przypadku gospodarstw ogółem o poziomie wyników końcowych zadecydował w dużym stopniu poziom dopłat do działalności produkcyjnej oraz inwestycyjnej uzyskiwany przez gospodarstwa rolne. Według metodyki FADN dopłaty do działalności gospodarstw rolnych są ujmowane przy obliczaniu dochodu z gospodarstwa rolnego.

Udział dopłat w dochodach gospodarstw rolnych ogółem wyniósł około 70\%, natomiast gospodarstw specjalizujących się w produkcji ogrodniczej - 12-14\%, co wskazuje na dominująca rolę dopłat w kształtowaniu poziomu dochodów ogółu gospodarstw rolnych. Dopłaty do działalności gospodarstw rolnych mają znaczący udział w dochodach zarówno gospodarstw rolnych w Polsce, jak i pozostałych krajów UE.

W krajach UE-15, od 1995 roku udział dopłat w dochodach gospodarstw rolnych ogółem był przeważający i wzrastał, a w 2009 roku przekraczał nawet 100\% dochodów (Runowski, 2014). W Polsce bardzo wysoki poziom wsparcia dochodów jest obserwowany zwłaszcza w przypadku gospodarstw wielokierunkowych oraz nastawionych na uprawy polowe (Goraj, Mańko, 2013). W gospodarstwach specjalizujących się w produkcji warzyw poziom wsparcia dochodów wykazuje tendencję malejącą. Poza tym w tego typu polskich gospodarstwach jest on niższy niż w gospodarstwach warzywniczych innych krajów unijnych (Ziętara, Sobierajewska, 2013).

Efektywność ekonomiczną gospodarowania zasobami w badanych gospodarstwach ogrodniczych na tle ogółu gospodarstw rolnych, czyli dochodowość zasobów ziemi, wydatkowanej pracy i zaangażowanego kapitału przedstawiono w tabeli 5. W związku z tym, że poziom uzyskanych dochodów był wielokrotnie wyższy w przypadku gospodarstw nastawionych na produkcję ogrodniczą to wskaźniki dochodowości zasobów były także wyraźnie wyższe w tych gospodarstwach (mimo znacznie wyższego poziomu dopłat do dochodów ogółu gospodarstw rolnych, uwzględnianych przy obliczaniu wskaźników dochodowości zasobów).

Tabela 5. Efektywność ekonomiczna zasobów porównywanych gospodarstw w latach 2013-2015

Table 5. Economic efficiency of resources in comparable farms in 2013-2015

\begin{tabular}{l|rrrrrr}
\hline \multicolumn{1}{c|}{ Wyszczególnienie } & \multicolumn{5}{c}{ Gospodarstwa } \\
& \multicolumn{3}{c}{ ogółem } & \multicolumn{4}{c}{ Ogrodnicze } \\
& 2013 & 2014 & 2015 & 2013 & 2014 & 2015 \\
\hline Dochód z gospodarstwa rolnego na 1 ha UR [zł/ha] & 1999 & 1853 & 1706 & 11352 & 10132 & 14253 \\
Dochodowość pracy własnej [zł/osobę] & 26325 & 23395 & 22508 & 40132 & 37308 & 54470 \\
Dochodowość aktywów ogółem [\%] & 5,7 & 5,1 & 4,6 & 11,5 & 10,4 & 14,6 \\
\hline
\end{tabular}

Źródło: jak w tab. 1. 
W latach 2013-2014 dochodowość zasobów ziemi gospodarstw ogrodniczych była prawie sześciokrotnie większa niż ogółu gospodarstw, a w 2015 r. - ponad ośmiokrotnie. Dochodowość pracy własnej w latach 2013-2014 w tychże gospodarstwach była większa o ponad 50\%, a w 2015 r. o $142 \%$, natomiast dochodowość kapitału gospodarstw ogrodniczych była większa odpowiednio: dwu- i trzykrotnie.

\section{Podsumowanie}

Analizowane gospodarstwa nastawione na produkcję ogrodniczą w porównaniu do ogółu gospodarstw rolnych użytkowały znacznie mniejszą powierzchnię zasobów ziemi (ponad trzykrotnie mniejsza), angażowały większe nakłady pracy, ale poziom ich wyników produkcyjnych był wyraźnie wyższy niż gospodarstw ogółem. W rezultacie, efektywność produkcyjna czynników wytwórczych gospodarstw ogrodniczych ukształtowała się na znacznie wyższym poziomie niż ogółu gospodarstw, zwłaszcza produktywność ziemi, która była wielokrotnie większa, ale także kapitału (ponad dwukrotnie większa).

Gospodarstwa specjalizujące się w produkcji ogrodniczej uzyskały wyniki ekonomiczne na kilkukrotnie wyższym poziomie niż gospodarstwa ogółem, dlatego przewyższały je bardziej efektywnością ekonomiczną niż produkcyjną, zwłaszcza w gospodarowaniu zasobami ziemi, jak również kapitału.

Należy podkreślić, że wpływ niekorzystnych warunków pogodowych na pogorszenie wyników produkcyjnych i ekonomicznych w rolnictwie miał miejsce w przypadku ogółu badanych gospodarstw, natomiast $\mathrm{w}$ gospodarstwach ogrodniczych zmniejszenie zbiorów warzyw zrekompensowane znaczącym wzrostem ich cen przyczyniło się nawet do poprawy wyników tychże gospodarstw. Ponadto na podkreślenie zasługuje fakt, że dopłaty do działalności gospodarstw nastawionych na produkcję ogrodniczą nie mają dużego wpływu na poziom dochodów uzyskiwanych przez te gospodarstwa. Mają one także mniejszy udział w dochodach polskich gospodarstw nastawionych na produkcję warzyw niż w dochodach tego typu gospodarstw w innych krajach unijnych.

\section{Literatura}

Brzozowski, P., Zmarlicki, K. (2015). Koszty i opłacalność produkcji warzyw polowych w latach 2012-2015 (Costs and profitability of open-field production of vegetables in the years 2012-2015), Zeszyty Naukowe Instytutu Ogrodnictwa, 23, 5-16.

Farm economy focus by sector. Farms specialised in horticulture in the EU, European Commission, 2017. Pobrane z: https:/ec.europa.eu/agriculture/sites/agriculture/files/fadn/documents/orchards_en.pdf.

Filipiak, T. (2014). Zmiany na rynku warzyw i w gospodarstwach warzywniczych w Polsce po integracji z Unią Europejską (Changes on the vegetable market and vegetable farms in Poland after integration with the European Union), SGGW, Warszawa.

Goraj, L., Mańko, S. (2013). Analiza sytuacji ekonomicznej towarowych gospodarstw rolnych w latach 2004-2010 (Analysis of the economic situation of commodity farms in 2004-2010), Powszechny Spis Rolny 2010, GUS, Warszawa.

Goraj, L., Mańko, S. (2009). Rachunkowość i analiza ekonomiczna w indywidualnym gospodarstwie rolnym (Accounting and economic analysis in an individual farm), Centrum Doradztwa i Informacji Difin, Warszawa.

Jabłońska, L., Filipiak, T., Gunerka, L. (2017). Konkurencyjność kosztowa gospodarstw ogrodniczych w Polsce i wybranych krajach UE (The cost competitiveness of horticultural farms in Poland and selected EU countries), Zeszyty Naukowe SGGW Problemy Rolnictwa Światowego, 17(1), 63-72. 
Jabłońska, L., Gunerka, L., Hornowski, A. (2016). Produkcja warzyw w Polsce i wybranych krajach Unii Europejskiej w latach 2000-2014 (Vegetable production in Poland and selected European Union countries in the years 2000-2014). Roczniki Naukowe Stowarzyszenia Ekonomistów Rolnictwa i Agrobiznesu, 18(3), 101-107.

Jąder, K. (2017). Polski handel zagraniczny warzywami i ich przetworami w latach 2001-2015 (Polish foreign trade in vegetables and their products in 2001-2015). Zeszyty Naukowe SGGW Problemy Rolnictwa Światowego, 17(3), 154-165.

Józwiak, W. (1998). Efektywność gospodarowania w rolnictwie, Encyklopedia agrobiznesu (Effectiveness of managementin agriculture, Agribusiness Encyclopedia). Fundacja Innowacyjna, Warszawa.

Kapusta, F. (2012). Agrobiznes (Agribusiness). Centrum Doradztwa i Informacji Difin, Warszawa.

Nosecka, B., Bugała, A., Paszko, D., Zaremba, Ł. (2012). Sytuacja na światowym rynku wybranych produktów ogrodniczych i jej wpływ na polski rynek ogrodniczy (The situation on the global market for selected horticultural products and its impact on the Polish horticultural market). Konkurencyjność polskiej gospodarki żywnościowej w warunkach globalizacji i integracji europejskiej, nr 39, IERiŻ-PIB, Warszawa.

Nosecka, B. (2014). Zewnętrzne uwarunkowania wzrostu eksportu owoców, warzyw i ich przetworów z Polski (External conditions for the growth of exports of fruit, vegetables and their products from Poland). Roczniki Naukowe Ekonomii Rolnictwa i Rozwoju Obszarów Wiejskich, 101(3), 133-144.

Pawlak, K. (2014). Zmiany w polskim handlu zagranicznym produktami rolno-spożywczymi po akcesji do Unii europejskiej (Changes in Polish foreign trade in agri-food products after accession to the European Union). Zeszyty Naukowe SGGW Problemy Rolnictwa Światowego, 14(2), 170-184.

Rolnictwo w 2015 r. (Agriculture in 2015). GUS, Warszawa, 2016.

Rynek owoców $i$ warzyw, stan i perspektywy (Fruit and vegetable market, condition and prospects). IERiŻ-PIB, nr 50, Warszawa, 2017

Rynek rolny (Agricultural market), IERiŻ-PIB, nr 1(311), Warszawa, 2017.

Runowski, H. (2014). Ekonomika rolnictwa - przemiany w gospodarstwach rolnych (The economics of agriculture - changes in farms). W: N. Drejerska (red.), Rolnictwo, gospodarka żywnościowa, obszary wiejskie - 10 lat w Unii Europejskiej, SGGW, Warszawa, 31-48.

Wyniki standardowe 2013 uzyskane przez gospodarstwa rolne uczestniczace w Polskim FADN (Standard results for 2013 obtained by agricultural holdings participating in the Polish FADN). Warszawa, 2014. Pobrano z: www.fadn.pl.

Wyniki standardowe 2014 uzyskane przez gospodarstwa rolne uczestniczqce w Polskim FADN (Standard results for 2014 obtained by agricultural holdings participating in the Polish FADN). Warszawa, 2015. Pobrano z: www.fadn.pl.

Wyniki standardowe 2015 uzyskane przez gospodarstwa rolne uczestniczqce w Polskim FADN (Standard results for 2015 obtained by agricultural holdings participating in the Polish FADN). Warszawa, 2016. Pobrano z: www.fadn.pl.

Ziętara, W., Sobierajewska, J. (2012). Gospodarstwa ogrodnicze w Polsce i w wybranych krajach Unii Europejskiej (Horticultural holdings in Poland and in selected European Union countries). Konkurencyjność polskiej gospodarki żywnościowej w warunkach globalizacji i integracji europejskiej, nr 58, IERiŻ-PIB, Warszawa.

Ziętara, W., Sobierajewska, J. (2013). Polskie gospodarstwa warzywnicze na tle wybranych krajów Unii Europejskiej (Polish vegetable farms against the background of selected European Union countries). Naukowe SGGW Ekonomika i Organizacja Gospodarki Żywnościowej, 102, 67-86.

Do cytowania / For citation:

Komorowska D. (2018). Wyniki produkcyjne i ekonomiczne gospodarstw ogrodniczych. Problemy Rolnictwa Światowego, 18(1), 111-120; DOI: 10.22630/PRS.2018.18.1.10

Komorowska D. (2018). Production and Economic Results of Horticultural Farms (in Polish). Problems of World Agriculture, 18(1), 111-120; DOI: 10.22630/PRS.2018.18.1.10 